\title{
UPAYA PENINGKATAN INTERAKSI SOSIAL DAN PRESTASI BELAJAR MELALUI PENERAPAN MODEL PEMBELAJARAN LEARNING TOGETHER (LT) DILENGKAPI DENGAN KARTU PINTAR PADA MATERI STOIKIOMETRI BAGI PESERTA DIDIK KELAS X MIA-2 SMA BATIK 2 SURAKARTA TAHUN PELAJARAN 2015/2016
}

\author{
Annas Fahmi Ramadan, Haryono*, dan Bakti Mulyani \\ Program Studi Pendidikan Kimia, FKIP, Universitas Sebelas Maret, Surakarta, Indonesia \\ *Keperluan korespondensi, Hp: 08122624628, email: hharyono@yahoo.com
}

\begin{abstract}
ABSTRAK
Penelitian ini bertujuan untuk meningkatkan prestasi belajar dan interaksi sosial siswa melalui penerapan model pembelajaran Learning Together $(L T)$ dilengkapi kartu pintar pada materi pokok stoikiometri kelas X MIA-2 Semester Genap SMA Batik 2 Surakarta. Penelitian ini merupakan Penelitian Tindakan Kelas (PTK) yang terdiri dari dua siklus. Setiap siklus terdiri atas tahap perencanaan, tahap pelaksanaan, tahap observasi dan tahap refleksi. Penelitian dilakukan di kelas X MIA-2 SMA Batik 2 Surakarta tahun pelajaran 2015/2016. Data diperoleh melalui wawancara, observasi, tes dan angket. Teknik analisis data yang digunakan adalah analisis deskriptif kualitatif. Hasil penelitian menunjukkan bahwa prestasi belajar dan interaksi sosial siswa mengalami peningkatan dengan menerapkan model pembelajaran Learning Together $(L T)$ dilengkapi kartu pintar. Aspek pengetahuan mengalami peningkatan dari siklus I sebesar $62,50 \%$ menjadi $82,50 \%$ pada siklus II. Aspek Interaksi Sosial mengalami peningkatan dari 74,61\% pada siklus I menjadi $79,20 \%$ pada sikus II. Aspek sikap mengalami peningkatan dari dari siklus I sebesar $78,46 \%$ menjadi $82,25 \%$ pada siklus II. Aspek Sikap hanya ada pada siklus I yaitu sebesar $77,50 \%$.
\end{abstract}

Kata kunci: Learning Together (LT), interaksi sosial, prestasi belajar, media kartu pintar, stoikiometri

\section{PENDAHULUAN}

Dalam rangka mencerdaskan kehidupan bangsa, pendidikan merupakan salah satu upaya untuk mencapai citacita tersebut. Pendidikan yang baik akan melahirkan generasi yang baik pula maka pendidikan perlu ditingkatkan salah satunya yaitu degan mengembangkan kurikulum.

Kurikulum yang diterapkan pada SMA Batik 2 Surakarta adalah kurikulum 2013 dimana karakteristiknya yaitu mengembangkan keseimbangan antara pengembangan sikap spiritual dan sosial, rasa ingin tahu, kreativitas dan kerja sama dengan kemampuan intelektual dan psikomotorik [1]. Selain itu, dalam kurikulum 2013 tersebut terdapat upaya peningkatan mutu pendidikan yang salah satunya menyangkut cara meningkatkan kualitas metode dan model pembelajaran.

Dalam pelaksanannya pada proses pembelajaran di sekolah, kurikulum 2013 menuntut adanya minimalisir pembelajaran yang berpusat pada guru atau Teacher Centered Learning (TCL) dimana pembelajaran TCL ini menjadikan guru sebagai sumber informasi utama bagi peserta didik sehingga membuat mereka bergantung pada guru [2]. Akibatnya siswa cenderung kurang kreatif dalam memecahkan masalah, pasif dalam kegiatan pembelajaran, kurangnya kerjasama dalam kelompok, kegiatan 
belajar mengajar tidak efektif sehingga prestasi belajar menjadi rendah.

Berdasarkan observasi pada bulan September sampai dengan Oktober 2015, diperoleh informasi bahwa di SMA Batik 2 Surakarta terdapat 3 kelas X MIA, namun untuk penelitian tindakan kelas yang akan di lakukan adalah di kelas $X$ MIA-2. Pemilihan kelas ini didasarkan dari adanya beberapa permasalahan yang ada di kelas tersebut. Adapun permasalahan tersebut antara lain: 1) pada saat pembelajaran berlangsung, banyak siswa yang masih kurang mempersiapkan diri dalam belajar misalnya banyak siswa yang masih tidak membawa buku pegangan; 2) Siswa kurang mempunyai semangat belalajar, hal ini ditunjukan banyak siswa yang masih telat masuk kelas serta kurangnya perhatian siswa kepada guru pada saat proses pembelajaran berlangsung; 3) Kemampuan siswa dalam berkomunikasi masih minim sehingga memberikan dampak rendahnya kerjasama dalam ranah interaksi sosial; 4) Dalam berdiskusi kelompok yang bertujuan untuk belajar bersama, terlihat banyak siswa yang pasif serta belajar sendiri dikelompoknya, hal ini menunjukkan perpaduan antar anggota kelompok masih rendah dalam ranah interaksi sosial; 5) Siswa kurang berinteraksi serta cenderung bersifat individualistik pada saat melakukan diskusi kelompok. Hal ini menunjukkan interaksi sosial yang masih rendah pada siswa kelas X MIA-2.

Permasalahan yang telah disebutkan merupakan permasalaan yang mengindikasikan bahwa di SMA Batik 2 Surakarta aspek interaksi sosial rendah khususnya kelas $X$ dikarenakan peneliti memfokuskan penelitiannya pada kelas $X$ disamping materi penelitian adalah Stoikiometri. Selain adanya permasalahan tersebut, terdapat data nilai hasil ulangan akhir semester 1 yang mendukung pemilihan kelas $X$ MIA-2 sebagai objek dalam penelitian.

Tabel 1. Data Ketuntasan Siswa Kelas $X$ MIA UAS I Tahun Pelajaran 2015/2016 SMA Batik 2 Surakarta

\begin{tabular}{ccc}
\hline Kelas & KKM & $\begin{array}{c}\text { Ketuntasan } \\
(\%)\end{array}$ \\
\hline X MIA-1 & 70 & 62,79 \\
X MIA-2 & 70 & 56,85 \\
X MIA-3 & 70 & 58,68 \\
\hline
\end{tabular}

Selain pemilihan kelas $X$ MIA-2, peneliti lebih memfokuskan pada materi stoikiometri. Pemilihan materi stoikiometri pada penelitian ini adalah didasari pada ketuntasan nilai siswa ulangan harian stoikiometri kelas X SMA Batik 2 Surakarta yang dapat dilihat pada Tabel 2.

Tabel 2. Data Ketuntasan Siswa Kelas X MIA Materi Pokok Stoikiometri Tahun Pelajaran 2014/2015 SMA Batik 2 Surakarta

\begin{tabular}{ccc}
\hline Kelas & KKM & $\begin{array}{c}\text { Ketuntasan } \\
(\%)\end{array}$ \\
\hline X MIA-1 & 70 & 62,24 \\
X MIA-2 & 70 & 57,42 \\
X MIA-3 & 70 & 60,50 \\
\hline
\end{tabular}

Tabel 2 menunjukkan bahwa kelas X MIA-2 memiliki nilai ketuntasan paling rendah diantara kelas-kelas lainnya. Data tersebut juga didukung dari hasil wawancara terhadap siswa kelas X MIA2 tanggal 20 April 2016 yang menyatakan bahwa materi stoikiometri adalah materi yang paling sukar dipahami. Misalnya tentang subab konsep mol, siswa masih belum paham bagaimana mengubah satuan massa menjadi mol atau mengkonversikan volume menjadi mol dan lain sebagainya. Materi Stoikiometri kelas $\mathrm{X}$ adalah materi yang berkelanjutan yang akan dipelajari pada kelas XI serta kelas XII, sehingga diperlukan perbaikan dan peningkatan pembelajaran agar dapat mengatasi permasalahan di atas.

Permasalahan tersebut dapat diatasi dengan berbagai cara, diantaranya yaitu dengan mengubah model pembelajaran yang dapat meningkatkan interaksi sosial siswa kelas X MIA-2 serta dapat meningkatkan prestasi belajar yang tergolong masih rendah, kemudian peserta didik perlu dirangsang agar 
dalam proses belajar mengajar tidak lagi terpusat pada guru yang menjadi sumber utama informasi tetapi siswa yang harus aktif dalam mencari informasi tersebut. Pem-belajaran kooperatif merupakan alternatif pemecahan masalah diatas dimana pembelajaran kooperatif merupakan pembelajaran dengan cara siswa belajar dan bekerja dalam kelompok-kelompok kecil serta kolaboratif dengan stuktur kelompok yang bersifat heterogen.

Dalam pembelajaran kooperatif, interaksi siswa dalam proses pembelajaran dapat dilaksanakan lebih optimal. Hal ini dikarenakan model pembelajaran kooperatif berupa kelompok-kelompok kecil dengan memperhatikan keberagaman anggota kelompok sebagai wadah siswa bekerjasama dan memecahkan masalah serta memberikan kesempatan pada siswa untuk mempelajari sesuatu dengan baik pada waktu yang bersamaan dan menjadi narasumber bagi teman yang lain [3]. Pembelajaran kooperatif dapat menekankan aspek kerja sama dalam memecahkan suatu persoalan dimana pembelajaran kooperatif merupakan sebuah model pembelajaran yang memungkinkan siswa belajar dari teman sebayanya dalam sebuah kelompok [4].

Learning Together (LT) merupakan model pembelajaran kooperatif yang dikombinasikan dengan pembelajaran individual dimana dengan menggunakan model pembelajaran ini dapat menonjolkan pemikiran siswa dalam kelompok yang kemudian dipadukan menjadi satu sehingga tercapai tujuan kelompok [5]. Selain itu dampak yang timbul dalam mencapai tujuan kelompok tersebut adalah adanya interaksi antar siswa dalam satu kelompok. Oleh karena itu peneliti menggunakan model pembelajaran kooperatif Learning Together (LT) supaya interaksi sosial dan prestasi belajar siswa dapat meningkat.

Dalam pembelajaran Learning Together (LT) terdapat empat unsur bagian, yaitu 1) interaksi tatap muka dimana para siswa bekerja dalam kelompok beranggotakan empat sampai lima orang; 2) interpedensi positif merupakan unsur pembelajaran koopertif dimana anggota kelompok yamg berbagi tujuan bersama meng-anggap bahwa bekerja sama secara individual dan kolektif menguntungkan dan kesuksesan tergantung pada setiap partisipasi semua anggota; 3) tanggung jawab individu dimana para siswa memperlihatkan bahwa mereka secara individual telah menguasai materinya dan 4) kemampuan interpersonal dan kelompok kecil dimana para siswa diajari mengenai sasaran yang efektif untuk bekerja sama dan mendiskusikan seberapa baik kelompok mereka bekerja dalam mencapai tujuan kelompok [3].

Penelitian yang telah dilakukan oleh Okur dan Doymus menyatakan bahwa dengan menerapkan model pembelajaran Learning Together (LT), siswa mampu meningkatkan prestasi belajar, selain itu siswa lebih aktif dalam proses pembelajaran serta siswa termotivasi untuk lebih percaya diri dalam menyampaikan pendapat dan proses pembelajaran lebih menyenangkan [6]. Berdasarkan penelitian yang dilakukan oleh Sumpana menyatakan bahwa pembelajaran yang menerapkan kartu pintar dapat meningkatkan aspek kognitif serta meningkatkan aspek afektif siswa [7].

Berdasarkan uraian latar belakang diatas maka penulis bermaksud mengadakan penelitian dengan judul "Upaya Peningkatan Interaksi Sosial dan Prestasi Belajar melalui Penerapan Model Pembelajaran Learning Together (LT) dilengkapi dengan Kartu Pintar pada Materi Stoikiometri Bagi Peserta Didik Kelas X MIA-2 SMA Batik 2 Surakarta Tahun Pelajaran 2015/2016".

\section{METODE PENELITIAN}

Penelitian ini dilakukan di Kelas $X$ MIA-2 SMA Batik 2 Surakarta, Penelitian ini menggunakan metode Penelitian Tindakan Kelas yang dilaksankaan sebanyak dua Siklus. Setiap Siklus mempunyai empat tahap, yaitu tahap perencanaan, tindakan, observasi, dan refleksi. Subjek penelitian adalah siswa Kelas X MIA-2 SMA Batik 2 Surakarta 
Tahun Pelajaran 2015 / 2016. Sumber data berasal dari guru dan siswa.

Teknik pengumpulan data dilakukan melalui dua metode, yaitu metode tes untuk penilaian prestasi belajar aspek pengetahuan dan aspek ke-terampilan. Metode non tes untuk penilaian secara observasi, angket sikap, wawancara, dan kajian dokumen. Data dianalisis dengan teknik analisis kualitatif. Teknik analisis kualitatif yang dilakukan meliputi tiga komponen, yaitu reduksi data, penyajian data, dan penarikan kesimpulan.

Untuk memeriksa valid atau tidaknya data, menggunakan teknik yaitu teknik triangulasi. Triangulasi adalah teknik pemeriksaan keabsahan data yang memanfaatkan sesuatu yang lain di luar data itu untuk keperluan pengecekan atau sebagai pembanding terhadap data tersebut. Teknik triangulasi yang digunakan adalah teknik triangulasi pengumpulan data, untuk mengecek data kepada sumber yang sama dengan teknik yang berbeda [7].

Instrumen yang digunakan dalam penelitian ini adalah instrumen pembelajaran dan penilaian. Instrumen pembelajaran meliputi silabus, rencana pelaksanaan pembelajaran dan media kartu pintar yang melalui tahap validasi oleh panelis. Instrumen penilaian meliputi penilaian pengetahuan, sikap, keterampilan, dan interaksi sosial. Penilaian pengetahuan dilakukan validasi dan try out untuk mengetahui reliabilitas, taraf kesukaran item, dan daya pembeda item. Sedangkan untuk penilaian sikap dan interaksi sosial dilakukan validasi dan try out untuk mengetahui reliabilitas.

\section{HASIL DAN PEMBAHASAN}

Penelitian ini adalah Penelitian Tindakan Kelas dengan dua Siklus. Data yang diperoleh dalam penelitian adalah interaksi sosial dan prestasi belajar siswa pada materi pokok stoikiometri.

\section{Siklus I}

Pada siklus I terdiri dari 5 kali pertemuan untuk pembelajaran dan 1 kali pertemuan untuk tes evaluasi. Pada pembelajaran siswa terbagi menjadi kelompok dan tiap kelompok terdiri dari 5 siswa. Siswa menjadi pusat dari pembelajaran model Learning Together (LT) sedangkan guru hanya sebagai motivator dan fasilitator. Guru memberikan media kartu pintar yang digunakan sebagai media bantu siswa dalam proses pembelajaran. Keterlibatan siswa secara penuh dalam proses kegiatan pembelajaran akan mampu menciptakan pembelajaran yang aktif dan berpusat pada siswa dimana siswa tidak hanya sebagai objek tetapi juga sebagai subjek dalam proses pembelajaran.

Pada akhir siklus diberikan tes evaluasi pengetahuan, sikap dan interaksi sosial serta tes keterampilan. Tes pengetahuan berupa tes objektif pilihan ganda sedangkan tes evaluasi sikap dan interaksi sosial berupa pengisian angket dan observasi dan tes keterampilan berupa soal uraian. Target dan ketercapaian Siklus I dapat dilihat pada Tabel 3.

Tabel 3. Target dan Ketercapaian Siklus I Materi Stoikiometri Kelas X MIA-2 Tahun Pelajaran 2015/2016 SMA Batik 2 Surakarta

\begin{tabular}{|c|c|c|c|}
\hline $\begin{array}{l}\text { Aspek yang } \\
\text { Dinilai }\end{array}$ & $\begin{array}{c}\text { Target } \\
(\%)\end{array}$ & $\begin{array}{l}\text { Keter- } \\
\text { capaian } \\
(\%)\end{array}$ & Kriteria \\
\hline Pengetahuan & 75 & 62,50 & $\begin{array}{c}\text { Belum } \\
\text { Tercapai }\end{array}$ \\
\hline Interaksi Sosial & 75 & 78,46 & Tercapai \\
\hline Sikap & 75 & 74,61 & $\begin{array}{c}\text { Belum } \\
\text { Tercapai }\end{array}$ \\
\hline Keterampilan & 75 & 77,50 & Tercapai \\
\hline
\end{tabular}

Dari hasil siklus I aspek pengetahuan dan aspek sikap masih belum mencapai target, sehingga diperlukan adanya tindakan siklus II yang bertujuan untuk memperbaiki pembelajaran sehingga target yang diharapkan dapat terpenuhi.

\section{Siklus II}

Siklus II merupakan perbaikan dari siklus I terdiri dari 1 kali pertemuan untuk pembelajaran pengayaan pada indikator kompetensi yang belum tuntas men- 
capai target dan 1 kali pertemuan untuk remedial tes pengetahuan.

Target dan ketercapaian masingmasing aspek pada siklus II dapat dilihat dalam Tabel 4.

Tabel 4. Target dan Ketercapaian Siklus II Materi Stoikiometri Kelas X MIA2 Tahun Pelajaran 2015/2016 SMA Batik 2 Surakarta

\begin{tabular}{lccc}
\hline $\begin{array}{c}\text { Aspek yang } \\
\text { Dinilai }\end{array}$ & $\begin{array}{c}\text { Target } \\
(\%)\end{array}$ & $\begin{array}{c}\text { Keter- } \\
\text { capaian } \\
(\%)\end{array}$ & Kriteria \\
\hline Pengetahuan & 75 & 82,50 & Tercapai \\
Interaksi Sosial & 75 & 82,25 & Tercapai \\
Sikap & 75 & 79,19 & Tercapai \\
Keterampilan & 75 & 77,50 & Tercapai \\
\hline
\end{tabular}

Dari hasil siklus II semua aspek sudah mencapai target yang ditentukan dengan demikian penelitian ini dikatakan berhasil selain itu pembagian kelompok siklus I berbeda dengan siklus II. Hal ini bertujuan untuk meratakan dan memberikan kesempatan siswa agar bekerjasama dengan siswa lainnya.

\section{Perbandingan Antar Siklus}

Hasil penelitian menunjukkan bahwa dengan penerapan model pembelajaran Learning Together (LT) terjadi peningkatan pada masing-masing aspek dari siklus I ke siklus II. Aspek yang dinilai adalah aspek pengetahuan, sikap, keterampilan dan interaksi sosial. Berdasarkan hasil penelitian diperoleh perbandingan hasil aspek antar siklus yang dapat dilihat dalam Gambar 1 .

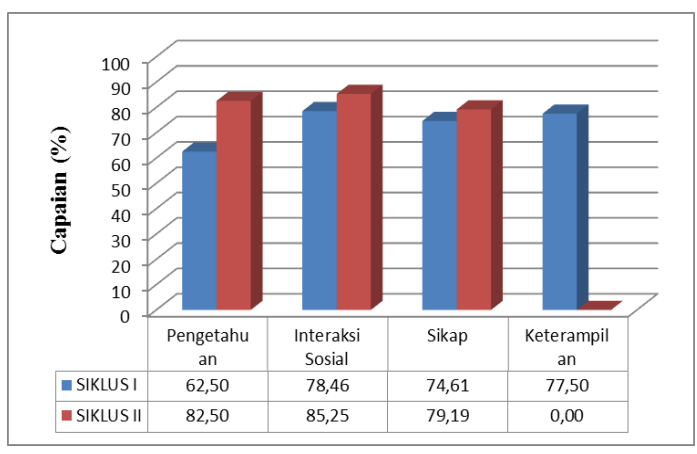

Gambar 1. Perbandingan Hasil Capaian antar Siklus
Dari hasil tersebut, terlihat bahwa penerapan model Learning Together (LT) dilengkapi media kartu pintar dapat meningkatkan aspek prestasi belajar dan interaksi sosial. Penggunaan model pembelajaran Learning Together (LT) menerapkan student centered learning dimana pembelajaran lebih terpusat pada siswa itu sendiri. Siswa bekerja sama dengan siswa yang lain untuk menyelesaikan permasalahan yang ada dalam kegiatan belajar mengajar.

Model Learning Together (LT) yang menerapkan konsep belajar bersama dalam proses pembelajaran membantu siswa untuk lebih melatih kerjasama. Siswa lebih menghargai pendapat siswa lainnya sehingga dalam pengambilan keputusan dapat diperoleh keputusan yang tepat hasil dari musyarawah yang dilakukan. Model pembelajaran Learning Together $(L T)$ yang diterapkan dengan diskusi dilakukan oleh siswa dengan siswa dalam kelompok dan siswa dengan guru. Adanya diskusi ini yang menyebabkan interaksi sosial siswa mengalami peningkatan. Selain model, media juga memegang peranan penting. Dalam pembelajaran ini menggunakan media kartu pintar. Media kartu pintar disajikan dalam bentuk kartu yang berisikan rumus-rumus terkonsep stoikiometri sehingga membantu siswa dalam menyelesaikan permasalahan soal yang diberikan oleh guru.

Media kartu pintar membantu siswa dalam bekerja sama memecahkan masalah yang diberikan. Kerjasama yang terjalin dengan baik antar siswa dalam kelompok mengindikasikan interaksi sosial siswa yang mulai meningkat. Selain itu, tanggung jawab siswa juga mengalami peningkatan dengan adanya media kartu pintar karena siswa mempunyai tanggung jawab memecahkan setiap permasalahan yang akan diselesaikan.

Berdasarkan perbandingan antar siklus dapat disimpulkan bahwa penelitian dengan menerapkan model pembelajaran Learning Together (LT) yang dilengkapi dengan media kartu pintar adalah berhasil dengan meningkatkan prestasi belajar dan interaksi sosial pada pembelajaran 
stoikiometri siswa kelas X MIA-2 SMA Batik 2 Surakarta tahun pelajaran 2015/2016. Keberhasilan dilihat dari ketercapaian persentase masing-masing aspek sudah melampaui target yang telah ditentukan dan mengalami peningkatan baik di siklus I ke siklus II.

Keberhasilan dari penelitian ini adalah penerapan model pembelajaran Learning Together (LT) yang dilengkapi dengan media kartu pintar. Dengan model Learning Together $(L T)$, siswa menjadi terlatih untuk bekerjasama dalam hal belajar menyelesaikan permasalahan yang ada sehingga interaksi sosial siswa juga mengalami peningkatan. Hal ini juga di dukung oleh penelitian sebelumnya, yang menyimpulkan bahwa pembelajaran Learning Together ( $L T)$ memiliki dampak positif dalam meningkatkan prestasi belajar siswa dan meningkatkan aktivitas belajar selama proses pembelajaran.

\section{KESIMPULAN}

Berdasarkan hasil penelitian dapat diambil kesimpulan bahwa penerapan pembelajaran Learning Together (LT) dilengkapi media kartu pintar dapat meningkatkan prestasi belajar dan interaksi sosial siswa kelas X MIA-2 SMA Batik 2 Surakarta tahun pelajaran 2015/2016. Hal ini dapat dilihat berdasarkan persentase hasil pelaksanaan tindakan kelas siklus I dan siklus II, Aspek pengetahuan mengalami peningkatan dari siklus I sebesar $62,50 \%$ menjadi $82,50 \%$ pada siklus II. Aspek Interaksi Sosial mengalami peningkatan dari $74,61 \%$ pada siklus I menjadi $79,20 \%$ pada sikus II. Aspek sikap mengalami peningkatan dari dari siklus I sebesar $78,46 \%$ menjadi $82,25 \%$ pada siklus II. Aspek Sikap hanya ada pada siklus I yaitu sebesar $77,50 \%$.

\section{UCAPAN TERIMA KASIH}

Penulis mengucapkan terima kasih kepada Bapak Soewarto, M.M Selaku Kepala Sekolah dan Bapak Ispriyanto, M.Pd selaku Guru Mata Pelajaran Kimia SMA Batik 2 Surakarta yang telah mengizinkan peneliti mengadakan penelitian di kelas X MIA-2.

\section{DAFTAR RUJUKAN}

[1] Kementerian Pendidikan dan Kebudayaan. (2014). Permendikbud Nomor 104 Tahun 2014 tentang Pembelajaran pada Pendidikan Dasar dan Menengah dan Pendidikan Menengah. Jakarta: Direktorat Kementrian Pendidikan dan Kebudayaan.

[2] Arikunto, S. (2013). Penelitian Tindakan Kelas. Jakarta: Bumi Aksara.

[3] Slavin, R. E. (2010). Cooperative Learning Teori, Riset dan Praktik. Terj. Yusron, Narulita. Bandung: Nusa Media.

[4] Rusman. (2012). Model-model Pembelajaran Mengembangkan Profesionalisme Guru. Jakarta: PT Raja Grafindo Persada.

[5] Isjoni. (2013). Cooperative Learning. Bandung: Alfabeta.

[6] Okur \& Doymus. (2014). The Effect of Diffrent Metods of Cooperative Learning Model on Academic Achievement in Physic. Journal of Turkish Science Education 11(4): 17-30.

[7] Sumpana. (2014). Pengembangan Pembelajaran Menerapkan Budaya Hidup Sehat Menggunakan Media Kartu Pintar Siswa Kelas IV SDN 01 Sekaran Semarang. Journal of Physical Education, Sport \& Health.

[8] Moleong, L.J. (2007). Metode Penelitian Kualitatif. Bandung: PT. Remaja Rosdakarya 